\title{
Analysis of Essential Elements in Commercially Important Lobster Species Collected From Coastal Areas of Karachi City, Pakistan
}

\author{
Tuba Kamal", Muhammad Asad Khan Tanoli, Majid Mumtaz and Sara Ayub
}

\author{
Department of Chemistry, Faculty of Science, University of Karachi-75270 Karachi, Pakistan
}

\begin{abstract}
The study was undertaken to assess the sea food product having attractive environmental effects as they are important source of nutrients in human diets. A part from delicacy crustacean is of high value and appreciated food items, representing an important economic source in the last decade. The chemical composition and nutritional value of crustacean heavily investigated worldwide and composition benefit to human health have been much promoted. The lack of macronutrients in human leads to improper enzyme mediated metabolic functions and results in organo-malfunctions, chronic diseases and ultimately death. The aim of this study is to quantify the essential elements like Copper, Zinc, Sodium, Potassium, Calcium and Magnesium in different body parts of male and female lobster species. For this purpose lobster species were collected in year 2011 to 2013 from the different fish harbor of Karachi city. Atomic Absorption Spectroscopy (AAS) technique was used to analyze the $\mathrm{Cu}, \mathrm{Zn}, \mathrm{Ca}$ and $\mathrm{Mg}$ while Flame photometer was used to quantify the $\mathrm{Na}$ and $\mathrm{K}$. The results were compared on the basis of WHO/ FAO values. The concentrations of selected essential metals were within the normal range in all the analyzed samples. Pearson correlation were applied to find out the inter metal relationship in different parts of lobster at significant level $p<0.01$ or $p<0.05$ and were found maximum relationship between the metals $\mathrm{Cu}: \mathrm{Zn}, \mathrm{Zn}: \mathrm{Na}, \mathrm{Zn}: \mathrm{K}, \mathrm{Na}: \mathrm{K}, \mathrm{Na}: \mathrm{Ca}, \mathrm{Na}: \mathrm{Mg}, \mathrm{K}: \mathrm{Mg}$ and $\mathrm{Ca}: \mathrm{Mg}$ in whole three years studied indicate that the strong correlation between the macronutrients and increasingly adverse impact of industrialization and urbanization on the commercially important lobsters community day by day.
\end{abstract}

Keywords: Lobster, Essential Elements, Karachi Coastal Areas, AAS and Flame Photometer.

\section{INTRODUCTION}

Sea food products are considered in worldwide as the good source of nutrients in human diet [1]. Especially, crustacean species reflect the highly rich composition of protein, calcium, vitamins and various extractable compounds [2]. On these basis decapods crustacean represents an important economic source.

Aquatic animals mainly the phyla crustacean species are the bio-indicators of toxic materials because invertebrates have more tendencies to accumulate more contaminants as compare to fishes [3]. Hazardous materials from the surrounding continuously enter in marine environment and deposit in biota from where it subsequently transferred to human through the food chain and when the concentration of these materials reach a certain level it become toxic [4].

Raising level of metals contaminants in aquatic ecosystem due to anthropogenic activities can alter the concentration of various essential elements in the marine environment. Some metals are essential in low concentration for the metabolism of animals [4-5]. The deficiency of essential elements (Calcium, magnesium, sodium, potassium, copper and zinc etc.,) causes the irregulation of enzymes performing metabolic functions

*Address correspondence to this author at the Department of Chemistry, Faculty of Science, University of Karachi, 75270, Karachi, Pakistan; Tel: 99261300-6; E-mail: lion.chemistry@gmail.com and results in organo malfunctions, chronic diseases and ultimately death [6].

Previous investigation were shown that declinement condition of aquatic environment due to the metal contamination and is one of the most critical environmental issues in worldwide countries and in developing Asian countries of increasing population and their expanding economic activities near the littoral zone [7]. Latest researches on the chemical composition and nutritional value of crustaceans and composition benefits to human health have been much promoted in the recent years but information is still rather dispersing [6].

Pakistan has geologically and ecologically diverse coastline dissected by harbors, estuaries, bays and creeks exhibiting wide characteristics in the marine species [8]. Unfortunately, the littoral state of Pakistan is facing much environmental issues as increasing pollution and human induced environmental changes particularly fishing, coastal aquaculture, waste disposal, industrial activity, agriculture, domestic effluents, salt making and unplanned tourism etc. Contaminated ecosystem destroys the live of aquatic animals and decreases the market value of seafood products and increase in bacterial diseases. Continuous deterioration of water quality is upsetting the ecological balance of coastal ecosystem. One impact identified is loss of critical habitats like coastal and estuarine wetlands; mangroves [9]. 


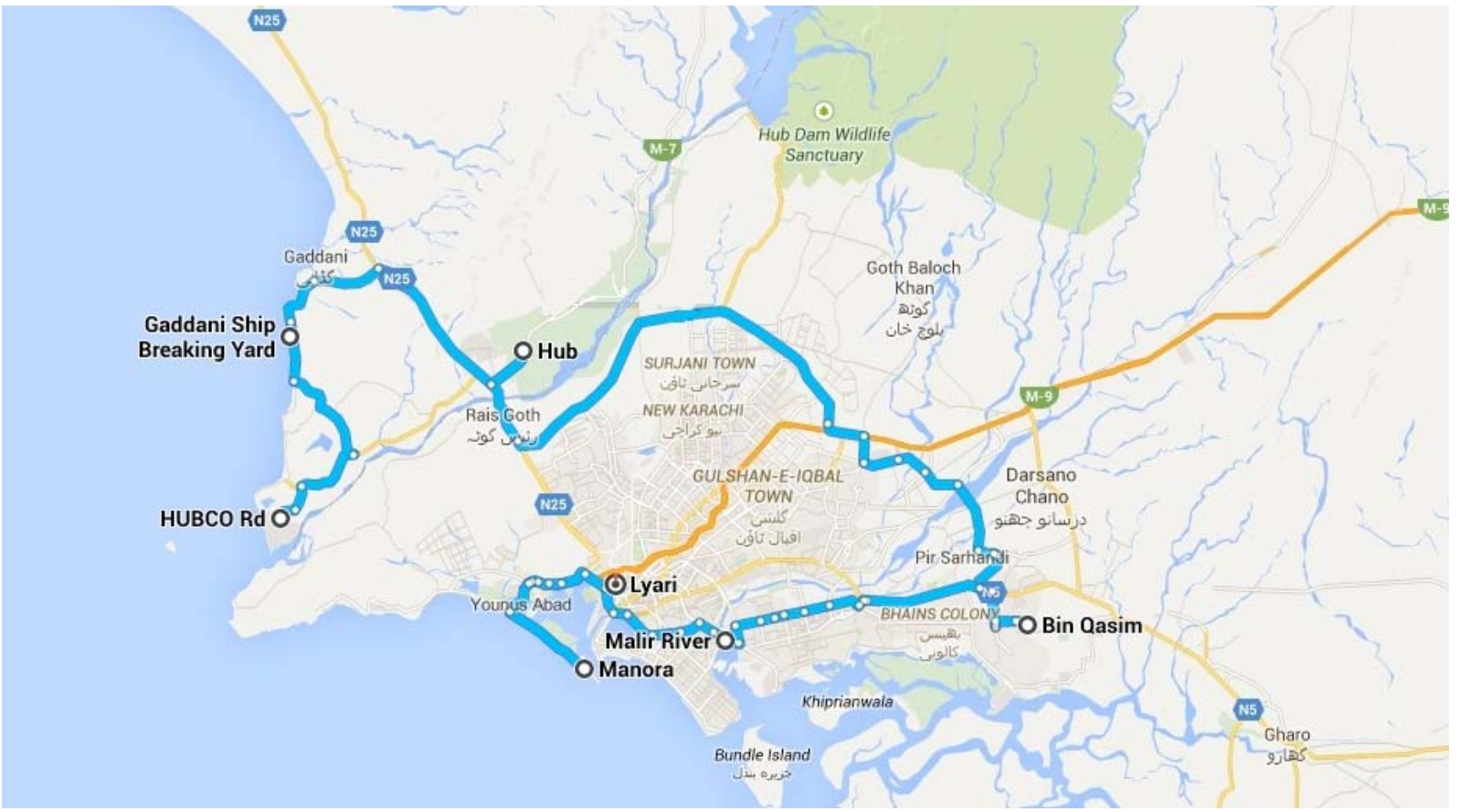

Figure 1: Map of Karachi City highlighting the selected coastal areas.

Absence of such information on population and variation in species has been a great handicap for fishing industry in Pakistan on modern lines [8]. Therefore it is necessary to assess the quality of aquatic animals because of rapid increase in environmental pollution.

The present paper aims to highlight the accumulation level of selective essential metals like $\mathrm{Zn}$, $\mathrm{Cu}, \mathrm{Na}, \mathrm{K}, \mathrm{Ca}$ and $\mathrm{Mg}$ in the different body parts of commercially important species of lobster collected from the various fish harbor of Karachi city (Figure 1). Perkin Elmer precisely atomic absorption spectroscopy A-Analyst 700 and Sherwood scientific corning 400 flame photometer technique were used to analyze the digested metals in bio-samples and were interpreted statistically by using SPSS version 17.0.

\section{MATERIALS AND METHODS}

Bio-samples (lobsters) were collected during the year 2011 to 2013 at different points of fish harbor area of Karachi city. The lobster species studied here is of commercial interest on a local and a national scale. These species have been exported to different countries, represent as an important food source. They were obtained directly from the fishing boats with a scoop net. After harvesting immediately packed in ice box inside sealed plastic bags with particularly specified tags and were transported to the lab within 1$2 \mathrm{hr}$. Samples were weighed and washed under the tap water to remove the adhere sediments particles from the body of the organisms. This was then cleaned with distilled and deionized water [10]. Lobsters in premoult or that had recently moulted were not used.

To minimize trace elements contamination, all lab wares were washed first with detergent and tap water and then soaked in 15\% nitric acid for $24 \mathrm{hr}$, rinsed repeatedly in deionized water and then dried prior to use. Furthermore, to minimize contamination of the samples, all chemicals used were of a HPLC grade.

\section{Essential Metals Analysis}

Male and female lobsters were separated and lengths were measured, mentioned in Table 1. For detail analysis samples were dissected and remove the shells. The edible tissues, exoskeleton and eggs were dried to a constant weight in an oven at $70^{\circ} \mathrm{C}$. After drying again weight were noted of each samples that was the original weight of samples. After that samples were ground to a fine powder. $4 \mathrm{~g}$ of each samples species were taken and treat it with a mixture of $\mathrm{HNO}_{3}$, $\mathrm{H}_{2} \mathrm{SO}_{4}$ and $\mathrm{HClO}_{4}$ in a ratio of 2:1:1 for the complete digestion. After digestion the solution was evaporated nearly to dryness on hot plate at $65-70^{\circ} \mathrm{C}$ and the required volume was filtered with whatmann-542 filter paper and diluted up to $100 \mathrm{ml}$ with $1 \% \mathrm{HNO}_{3}$ and kept at $4^{0} \mathrm{C}$ prior to further analysis. Finally elements contents in the samples were analyzed using AAS and flame photometer against working standards solution of different concentrations [11, 5]. Working standard solutions were prepared by appropriate dilution of 
Table 1: Sample Characteristics (the Sampling Years, Male and Female, Average Wet Weights and Total Lengths of Lobsters were Measured)

\begin{tabular}{|c|c|c|c|c|c|c|c|}
\hline & & \multicolumn{3}{|c|}{ L \pm SD } & \multicolumn{2}{c|}{ W SD } \\
\hline Years & & $\mathbf{2 0 1 1}$ & $\mathbf{2 0 1 2}$ & $\mathbf{2 0 1 3}$ & $\mathbf{2 0 1 1}$ & $\mathbf{2 0 1 2}$ & $\mathbf{2 0 1 3}$ \\
\hline Samples & $\boldsymbol{n}$ & & & & & & \\
\hline \hline Males & 4 & $27.2 \pm 0.4$ & $26.5 \pm 1.1$ & $28.0 \pm 0.5$ & $169.86 \pm 8.0$ & $114.40 \pm 11.4$ & $300.23 \pm 10.2$ \\
\hline Females & 4 & $30.0 \pm 0.6$ & $29.7 \pm 1.6$ & $31.2 \pm 0.3$ & $144.89 \pm 7.9$ & $124.64 \pm 4.5$ & $200.54 \pm 5.6$ \\
\hline
\end{tabular}

$\mathrm{W}$ - mean body weight $(\mathrm{g})$; SD - standard deviation; $\mathrm{L}$ - mean total length $(\mathrm{cm})$.

Table 2: Percent Recoveries of Essential Elements in Aquaculture Lobster

\begin{tabular}{|c|c|c|c|}
\hline Essential Elements & \% Recoveries & Essential Elements & \% Recoveries \\
\hline \hline $\mathrm{Cu}$ & 99 & $\mathrm{~K}$ & 91 \\
\hline $\mathrm{Zn}$ & 95 & $\mathrm{Ca}$ & 98 \\
\hline $\mathrm{Na}$ & 89.5 & $\mathrm{Mg}$ & 85 \\
\hline
\end{tabular}

$1 \mathrm{ppm}$ stock standard solution, which was prepared by using the 1000ppm standard solutions of fisher scientific UK. All the analysis was undertaken at least in triplicate on each sample and the mean values calculated. As no certified reference material (CRM) of shellfish (lobster) was available, the accuracy of the adopted procedure was assessed by the analysis of aquaculture growing lobster in Fish Harbor of Karachi city. Recoveries were consistently in the range of good agreement and were found certified and standard values (Table 2).

\section{Statistical Analysis}

Bio-concentration potential of macronutrients in aquatic samples which were sampling in three different years, were statistically analyzed by SPSS version 17.0. Pearson correlation was applied to find out inter metal relationship in different parts of male and female lobsters. The criterion values of probabilities $(p<0.01$ or $p<0.05$ ) for correction significance were used.

\section{RESULT AND DISCUSSION}

Bioaccumulation potential of hazardous materials in aquatic organisms based upon the environmental factors like food sources, dissolved metals, dissolve oxygen, interactions with metals and sediment, seasonal effects, geographical differences, genetic factors (body length and weight, development stage, sex, breeding condition, brooding, molting and growth). Results of different researches were found that potential level of metals in crustaceans can differ not only among different tissues but also between males and females [4]. The precision of technique was tested by replicate analysis of essential metals and prescribed in Table 2 using aquaculture lobster as certified reference material.

The mean concentrations of essential elements $\mathrm{Cu}$, $\mathrm{Zn}, \mathrm{Na}, \mathrm{K}, \mathrm{Ca}$ and $\mathrm{Mg}$ in commercially important lobster as $\mu \mathrm{g} / \mathrm{g}$ dry weight in 2011 to 2013 years studied are reported in Table 3.

In the current study, highest concentration of $\mathrm{Zn}$ and $\mathrm{Cu}$ were observed in the eggs of lobster in each year. The range of $\mathrm{Zn}$ varied from 7.96-173.61 $\mathrm{\mu g} / \mathrm{g}$ while that $\mathrm{Cu}, \mathrm{Na}, \mathrm{K}, \mathrm{Ca}$ and $\mathrm{Mg}$ were from $3.27-55.56 \mu \mathrm{g} / \mathrm{g}$, $383.20-3830.37 \mu \mathrm{g} / \mathrm{g}, \quad 299.83-4698.20 \mu \mathrm{g} / \mathrm{g}, \quad 1431.17$ $10729.82 \mu \mathrm{g} / \mathrm{g}$ and $397.54-6218.85 \mu \mathrm{g} / \mathrm{g}$ respectively. The $\mathrm{Zn}$ concentration was found higher in edible tissues as compare to the exoskeleton in case of both male and female lobsters. Concentrations were vary year to year but overall concentration was decrease in year 2012 as compare to the year 2011 and 2013 but not drastically decrease. High concentration of $\mathrm{Zn}$ in eggs shows the composite concentration. $\mathrm{Cu}$ concentration were also high in eggs as compare to the other samples mean while results also showed that concentration of $\mathrm{Cu}$ in samples which were collected in year 2012 found the high concentration as compare to the samples which were collected in year 2011, 2013 and were found the lower concentration of $\mathrm{Zn}$. In case of male samples concentration of $\mathrm{Cu}$ were high in tissues muscles as compare to exoskeleton but in case of female concentration of $\mathrm{Cu}$ were high in exoskeleton as compare to the muscles tissues.

The present study were interpretive that strong correlation found between $\mathrm{Cu}: \mathrm{Na}, \mathrm{Cu}: \mathrm{Ca}, \mathrm{Cu}: \mathrm{Mg}$ and 
Table 3: Mean Concentration ( $\mu$ g metal $\mathrm{g}^{-1} \mathrm{w} . \mathrm{w}$ ) and their Standard Deviation (Mean $\pm \mathrm{SD}$ ) of $\mathrm{Cu}, \mathrm{Zn}, \mathrm{Na}, \mathrm{K}, \mathrm{Ca}$ and $\mathrm{Mg}$ in the Muscle, Exoskeleton and Eggs of Male and Female Lobsters Collected during the Sampling Years (2011 to 2013) from the Coastal Areas of Karachi City

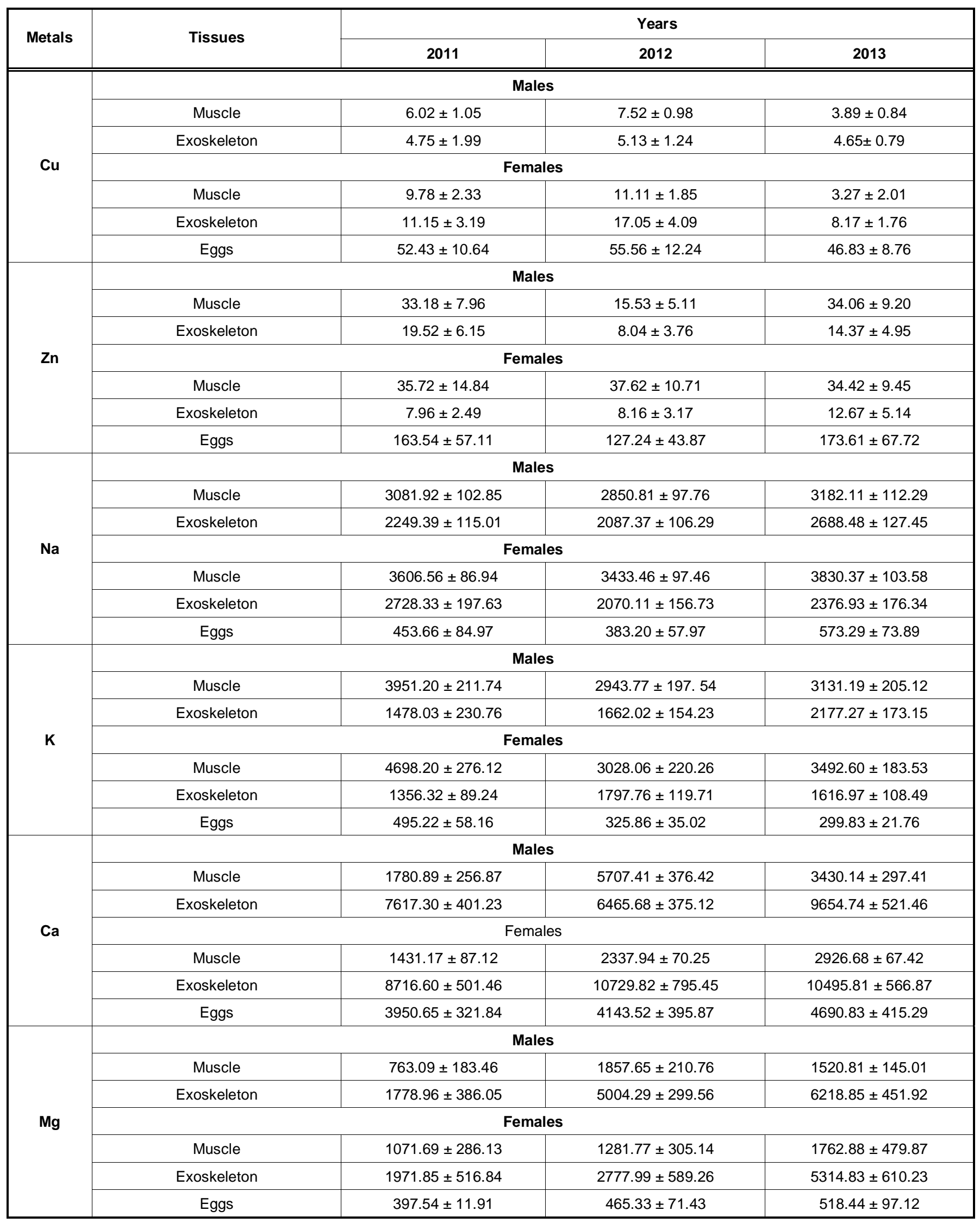


Table 4: The Pearson Correlation Matrix in Different Parts of Male and Female Lobsters at $p<0.01$ or $p<0.05$, in Year 2011

\begin{tabular}{|c|c|c|c|c|c|c|c|}
\hline Lobster male & & & & & & & \\
\hline \multirow{5}{*}{ muscles } & & $\mathrm{Cu}$ & $\mathrm{Zn}$ & $\mathrm{Na}$ & $\mathrm{K}$ & $\mathrm{Ca}$ & Mg \\
\hline & $\mathrm{Cu}$ & 1 & & & & & \\
\hline & $\mathrm{Na}$ & 0.99999629 & -0.9999451 & 1 & & & \\
\hline & $K$ & -0.9999896 & 0.9999949 & -0.999973 & 1 & & \\
\hline & Mg & 0.99931459 & -0.9995717 & 0.99921 & -0.9994732 & 0.99965869 & 1 \\
\hline \multirow[b]{4}{*}{ exo skeleton } & & $\mathrm{Cu}$ & $\mathrm{Zn}$ & $\mathrm{Na}$ & $\mathrm{K}$ & $\mathrm{Ca}$ & $\mathrm{Mg}$ \\
\hline & $\mathrm{Cu}$ & 1 & & & & & \\
\hline & $\mathrm{Zn}$ & 0.99941519 & 1 & & & & \\
\hline & $\mathrm{Na}$ & 0.99971946 & 0.9999447 & 1 & & & \\
\hline \multicolumn{8}{|l|}{ Lobster female } \\
\hline \multirow{7}{*}{ muscles } & & $\mathrm{Cu}$ & $\mathrm{Zn}$ & $\mathrm{Na}$ & $\mathrm{K}$ & $\mathrm{Ca}$ & $\mathrm{Mg}$ \\
\hline & $\mathrm{Cu}$ & 1 & & & & & \\
\hline & $\mathrm{Zn}$ & 0.99971478 & 1 & & & & \\
\hline & $\mathrm{Na}$ & -0.9997519 & -0.9999987 & 1 & & & \\
\hline & $K$ & -0.9999337 & -0.9999235 & 0.9999421 & 1 & & \\
\hline & $\mathrm{Ca}$ & -0.9998967 & -0.9999548 & 0.9999688 & 0.9999959 & 1 & \\
\hline & Mg & 0.99987031 & 0.9999697 & -0.999981 & -0.9999895 & -0.9999819 & 1 \\
\hline exo skeleton & Mg & 0.99994497 & -0.9873505 & -0.999998 & 0.9999991 & -0.9999819 & 1 \\
\hline \multirow{7}{*}{ eggs } & & $\mathrm{Cu}$ & $\mathrm{Zn}$ & $\mathrm{Na}$ & $\mathrm{K}$ & $\mathrm{Ca}$ & Mg \\
\hline & $\mathrm{Cu}$ & 1 & & & & & \\
\hline & $\mathrm{Zn}$ & -0.998639 & 1 & & & & \\
\hline & $\mathrm{Na}$ & -0.9985248 & 0.9999977 & 1 & & & \\
\hline & $K$ & -0.9989302 & 0.9999825 & 0.9999675 & 1 & & \\
\hline & $\mathrm{Ca}$ & -0.9988768 & 0.9999886 & 0.999976 & 0.9999993 & 1 & \\
\hline & Mg & -0.9989854 & 0.9999746 & 0.999957 & 0.9999993 & 0.99999724 & 1 \\
\hline
\end{tabular}

$\mathrm{Zn}: \mathrm{K}$ and $\mathrm{Cu}: \mathrm{Zn}, \mathrm{Cu}: \mathrm{Na}, \mathrm{Cu}: \mathrm{K}, \mathrm{Zn}: \mathrm{Na}, \mathrm{Zn}: \mathrm{Kin}$ edible tissues and exoskeleton of male lobsters respectively in year 2011. Strong relationship were also observed between (Cu:Zn, Cu:Mg, Zn:Mg), (Cu:K, Cu:Mg, Zn:Na, $\mathrm{Zn}: \mathrm{Ca})$ and ( $\mathrm{Zn}: \mathrm{Na}, \mathrm{Zn}: \mathrm{K}, \mathrm{Zn}: \mathrm{Ca}, \mathrm{Zn}: \mathrm{Mg})$ in edible tissues, exoskeleton and eggs of female lobsters respectively in year 2011. All the statistically applied results are presented at significant level $p<0.01$ or $p<$ 0.05 in Table 4.

The strong inter metal relationship were found between $\mathrm{Cu}: \mathrm{Zn}, \mathrm{Cu}: \mathrm{Na}, \mathrm{Cu}: \mathrm{K}, \mathrm{Zn}: \mathrm{Na}, \mathrm{Zn}: \mathrm{K}$ and $\mathrm{Zn}: \mathrm{Na}$, $\mathrm{Zn}: \mathrm{K}, \mathrm{Zn}: \mathrm{Ca}, \mathrm{Zn}: \mathrm{Mg}$ in edible tissues and exoskeleton of male lobsters respectively collected in year 2012 . Results were also showed the strong relationship 
Table 5: The Pearson Correlation Matrix in Different Parts of Male and Female Lobsters at $p<0.01$ or $p<0.05$, in Year 2012

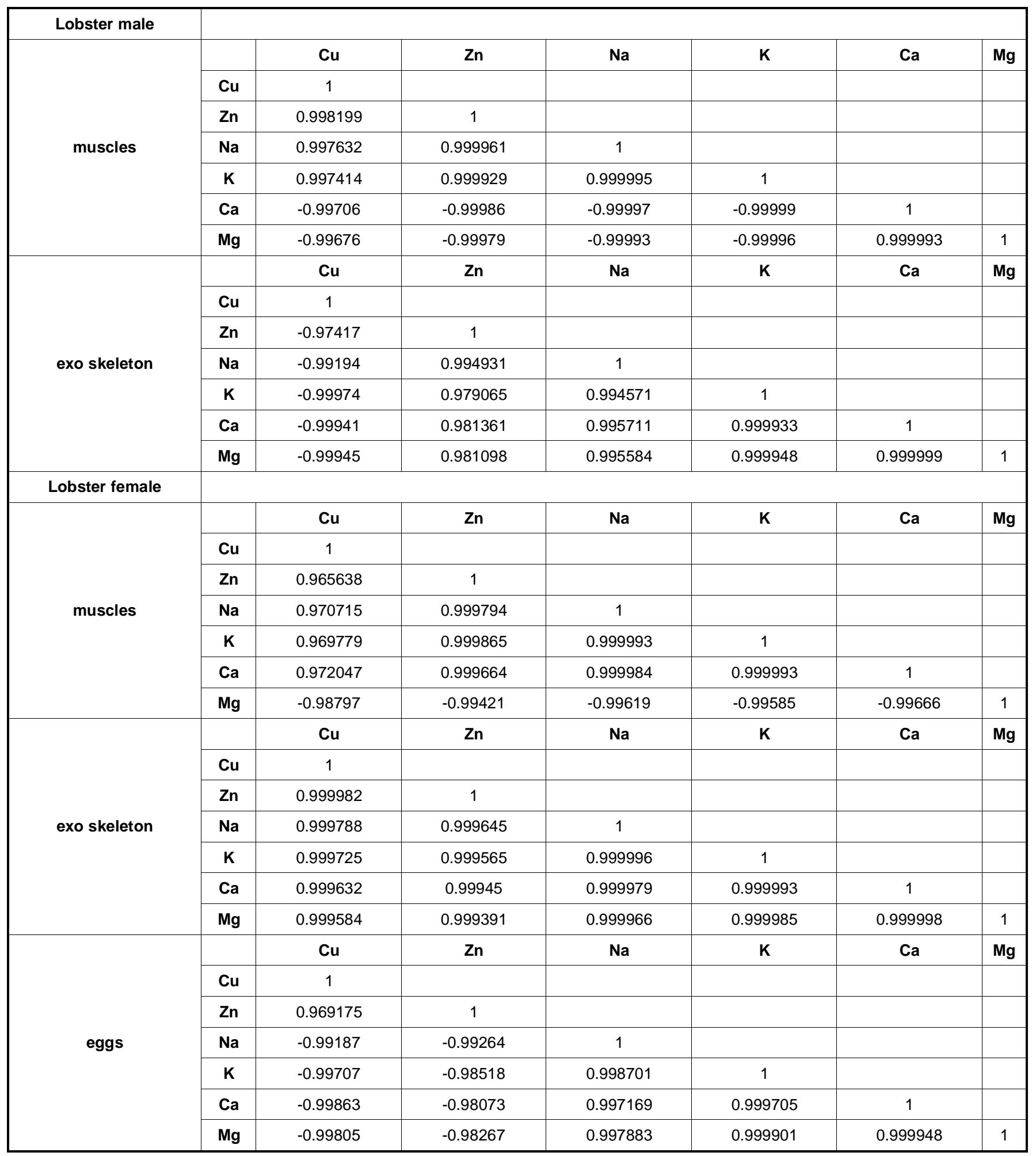

between (Cu:Zn, Cu:Na, Cu:K, Cu:Ca, Zn:Na, Zn:Ca, $\mathrm{Zn}: \mathrm{K})$, (Cu:Zn, Cu:Na, Cu:K, Cu:Ca, Cu:Mg, Zn:Na, $\mathrm{Zn}: \mathrm{K}, \mathrm{Zn}: \mathrm{Ca}, \mathrm{Zn}: \mathrm{Mg})$ and $(\mathrm{Cu}: \mathrm{Zn})$ in edible tissues, exoskeleton and eggs of female lobsters respectively in year 2012. Statistically interpretation of the results were showed at significant level $p<0.01$ or $p<0.05$ in Table 5.

In case of samples analyzed in year 2013, the strong correlation were observed between $\mathrm{Cu}: \mathrm{Zn}$ and $\mathrm{Cu}: \mathrm{Zn}, \mathrm{Cu}: \mathrm{Ca}, \mathrm{Zn}: \mathrm{Ca}$ in edible tissues and exoskeleton 
Table 6: The Pearson Correlation Matrix in Different Parts of Male and Female Lobsters at $p<0.01$ or $p<0.05$, in Year 2013

\begin{tabular}{|c|c|c|c|c|c|c|c|}
\hline Lobster male & & & & & & & \\
\hline \multirow{5}{*}{ Muscles } & & $\mathrm{Cu}$ & $\mathrm{Zn}$ & $\mathrm{Na}$ & $\mathrm{K}$ & $\mathrm{Ca}$ & Mg \\
\hline & $\mathrm{Cu}$ & 1 & & & & & \\
\hline & $\mathrm{Na}$ & -0.9987 & -0.99974 & 1 & & & \\
\hline & K & -0.99878 & -0.99977 & 0.999998 & 1 & & \\
\hline & $\mathbf{M g}$ & -0.99885 & -0.9998 & 0.999995 & 0.999999 & 0.999988 & 1 \\
\hline \multirow{4}{*}{ exo skeleton } & & $\mathrm{Cu}$ & Zn & $\mathrm{Na}$ & $\mathrm{K}$ & $\mathrm{Ca}$ & Mg \\
\hline & $\mathrm{Cu}$ & 1 & & & & & \\
\hline & $\mathrm{Zn}$ & 0.999965 & 1 & & & & \\
\hline & Mg & -0.99981 & -0.99994 & 0.999987 & 0.999991 & -0.99994 & 1 \\
\hline \multicolumn{8}{|l|}{ Lobster female } \\
\hline \multirow{6}{*}{ Muscles } & & $\mathrm{Cu}$ & $\mathrm{Zn}$ & $\mathrm{Na}$ & $\mathrm{K}$ & $\mathrm{Ca}$ & $\mathrm{Mg}$ \\
\hline & $\mathrm{Cu}$ & 1 & & & & & \\
\hline & $\mathrm{Zn}$ & -0.96792 & 1 & & & & \\
\hline & $\mathrm{Na}$ & -0.95975 & 0.999529 & 1 & & & \\
\hline & $\mathrm{K}$ & -0.9607 & 0.999628 & 0.999994 & 1 & & \\
\hline & $\mathrm{Ca}$ & 0.957033 & -0.99919 & -0.99995 & -0.99992 & 1 & \\
\hline \multirow{3}{*}{ exo skeleton } & $\mathrm{K}$ & -0.98457 & -0.98823 & 0.999067 & 1 & & \\
\hline & $\mathrm{Ca}$ & 0.980595 & 0.99128 & -0.99791 & -0.99977 & 1 & \\
\hline & Mg & -0.98428 & -0.98848 & 0.998993 & 0.999999 & -0.99981 & 1 \\
\hline \multirow{7}{*}{ Eggs } & & $\mathrm{Cu}$ & $\mathrm{Zn}$ & $\mathrm{Na}$ & $\mathbf{K}$ & $\mathrm{Ca}$ & Mg \\
\hline & $\mathrm{Cu}$ & 1 & & & & & \\
\hline & $\mathrm{Zn}$ & -0.99935 & 1 & & & & \\
\hline & $\mathrm{Na}$ & -0.99921 & 0.997136 & 1 & & & \\
\hline & $\mathrm{K}$ & -0.99852 & 0.995905 & 0.99989 & 1 & & \\
\hline & $\mathrm{Ca}$ & -0.99998 & 0.999134 & 0.999419 & 0.998804 & 1 & \\
\hline & Mg & -0.99817 & 0.995335 & 0.999781 & 0.999981 & 0.998487 & 1 \\
\hline
\end{tabular}

of male lobsters respectively and (Cu:Ca, $\mathrm{Zn}: \mathrm{Na}, \mathrm{Zn}: \mathrm{K}$, $\mathrm{Zn}: \mathrm{Mg})$, (Cu:Zn, Cu:Ca, Zn:Ca) and (Zn:Na, Zn:K, $\mathrm{Zn}: \mathrm{Ca}, \mathrm{Zn:Mg}$ ) in edible tissues, exoskeleton and eggs respectively of female lobster were also showed the strong inter metal relationship. Results were mentioned at significant level $p<0.01$ or $p<0.05$ in Table 6 .
The concentration of $\mathrm{Na}, \mathrm{K}$ were found that the very lowest concentration in eggs of lobsters and high concentration in edible tissues of female lobsters as compare to the male lobsters and exoskeleton had showed the low concentration of $\mathrm{Na}, \mathrm{K}$ of both male and female lobsters. Concentration of $\mathrm{Na}, \mathrm{K}$ was lower 
in some samples collected in year 2012. Bioconcentration of $\mathrm{Ca}$ and $\mathrm{Mg}$ were found higher in exoskeleton of both male and female lobsters as compare to the edible tissues, mean while were also observed that the edible tissues of female lobster consist of very low concentration $\mathrm{Ca}$. The year wise variation was not uniform for all the metals.

Statistically found the strong metal relationship between $\mathrm{Na}: \mathrm{Ca}, \mathrm{Na}: \mathrm{Mg}$, Ca:Mg and $\mathrm{Na}: \mathrm{K}, \mathrm{Ca}: \mathrm{Mg}$ in muscles tissues and exoskeleton of male lobsters respectively and (Na:K, Na:Ca, $\mathrm{K}: \mathrm{Ca}),(\mathrm{Na}: \mathrm{Ca}, \mathrm{K}: \mathrm{Mg}$ ) and (Na:K, Na:Ca, Na:Mg, K:Ca, K:Mg, Ca:Mg) in muscles tissues, exoskeleton and eggs of female lobster respectively, which were sampled in year 2011 and were presented in Table 4 at $p<0.01$ or $p<0.05$ significant level.

Positive correlation were also statistically found between $\mathrm{Na}: \mathrm{K}, \mathrm{Ca}: \mathrm{M} \mathrm{g}$ and $\mathrm{Na}: \mathrm{K}, \mathrm{Na}: \mathrm{Ca}, \mathrm{Na}: \mathrm{Mg}, \mathrm{K}: \mathrm{Ca}$, $\mathrm{K}: \mathrm{Mg}, \mathrm{Ca}: \mathrm{Mg}$ in edible tissues and exoskeleton of male lobster respectively and (Na:K, Na:Ca, K:Ca), (Na:K, $\mathrm{Na}: \mathrm{Ca}, \mathrm{Na}: \mathrm{Mg}, \mathrm{K}: \mathrm{Ca}, \mathrm{K}: \mathrm{Mg}, \mathrm{Ca}: \mathrm{Mg}$ ) and (Na:K, Na:Ca, $\mathrm{Na}: \mathrm{Mg}, \mathrm{K}: \mathrm{Ca}, \mathrm{K}: \mathrm{Mg}, \mathrm{Ca}: \mathrm{Mg}$ ) in muscles tissues, exoskeleton and eggs respectively of female lobsters, which were collected in year 2012 and were showed results in Table 5 at significant level $p<0.01$ or $p<0.05$.

Analyzed result were also found positive correlation between $\mathrm{Na}: \mathrm{K}, \mathrm{Na}: \mathrm{Ca}, \mathrm{Na}: \mathrm{Mg}, \mathrm{K}: \mathrm{Ca}, \mathrm{K}: \mathrm{Mg}, \mathrm{Ca}: \mathrm{Mg}$ and $\mathrm{Na}: \mathrm{K}, \mathrm{Na}: \mathrm{Mg}, \mathrm{K}: \mathrm{Mg}$ in edible tissues and exoskeleton of male lobsters in year 2013 respectively, while ( $\mathrm{Na}: \mathrm{K}$, $\mathrm{Na}: \mathrm{Mg}, \mathrm{K}: \mathrm{Mg}$ ), (Na:K, Na:Mg, K:Mg) and (Na:K, $\mathrm{Na}: \mathrm{Ca}, \mathrm{Na}: \mathrm{Mg}, \mathrm{K}: \mathrm{Ca}, \mathrm{K}: \mathrm{Mg}, \mathrm{Ca}: \mathrm{Mg}$ ) in edible tissues, exoskeleton and eggs of female lobster were also showed the inter metal positive correlation in year 2013 and presented in Table 6 at $p<0.01$ or $p<0.05$ significant level.

Bioaccumulation levels of macronutrients in different parts of male and female lobsters which were determined in sampling years (2011 to 2013) are also presented in Figure 2a, b, c, d, e and f.

\section{CONCLUSION}

The level of macronutrients varies in various species of aquatic animals and their environments. The level of macronutrients in aquatic animals varies in various species and different aquatic environments. These variations are presumably due to individual samples being categories of different size, ecological niches and tropic levels. Possibly, species also have different metabolic requirements for specific element
[12]. The present study focused the gender based analysis of exhibited significant spatial variation in metal level, which may be due to variations in environmental conditions for three years in Karachi region. The metals studied in this paper are essential elements (such as $\mathrm{Cu}, \mathrm{Zn}, \mathrm{Na}, \mathrm{K}, \mathrm{Ca}$ and $\mathrm{Mg}$ ). The main sources of these metals in the present geographical locate reflects that the effluents of Bin Qasim Thermal Power Plant, Sea Port activities and unloading of raw materials for Pakistan Steel Mill are the contributors of these metals, which further fractionated into water, seaweeds and sediments. The average concentration of pollutants reflects clearly the impact of local environment on the absorption of ionic elements in marine life. Industrial effluents coming through River Malir, sewage water and oil refinery situated in the coastal region are the other sources of $\mathrm{Cu}$ and $\mathrm{Zn}$ contamination. The industrial effluents of SITE (Sindh Industrial Trade Estate) through River Layari, exhibit the maximum $\mathrm{Cu}$ and $\mathrm{Zn}$ concentration in their flesh. Most probably the higher values of $\mathrm{Cu}$ and $\mathrm{Zn}$ is due to the industrial effluents of SITE area where different industries such as automobile, electroplating, textile, paints, dying, ceramic etc. are continues their production. The protruded landmass of Manora restricts free movement of shallow marine water in westward direction and dilution of seawater in respect of $\mathrm{Cu}, \mathrm{Zn}, \mathrm{Na}, \mathrm{K}, \mathrm{Ca}$ and $\mathrm{Mg}$ contents. As such the lobsters living in this marine environment encounter higher ionized metals which are absorbed by seaweed. These seaweeds served as a food for lobsters. The bad source of metals pollution from the industrial wastes of Hub industrial town is the effluents of Hubco Thermal Power Plant. Ship breading industry also contribute but in less amount of metal pollution in the marine ecosystem [13].Almost all metals measured in this study are relatively lower than the recommended values.

$\mathrm{Cu}$ and $\mathrm{Zn}$ are essential metals for normal growth, metabolism, enzymatic and respiratory processes of aquatic animals including crustaceans. High level of these two metals is very toxic to aquatic life [11].

Copper contaminations enter in marine organisms through food chain. Thus increasing ambient pollution levels in water do not directly affects the marine life. Copper is considered highly toxic metal after mercury and silver in marine life because the existence of a number of detoxifying and storage systems for $\mathrm{Cu}$ [12]. Levels of $\mathrm{Cu}$ in the muscle and exoskeleton of both male and female lobsters during the three year study shown in Table 2 and Figure 2a, far below the normal 


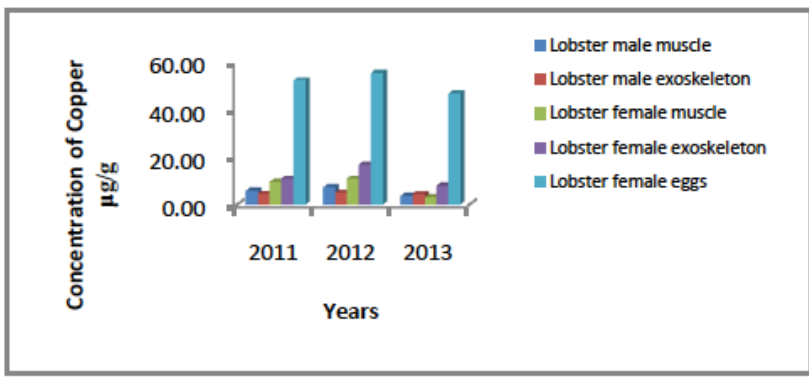

a

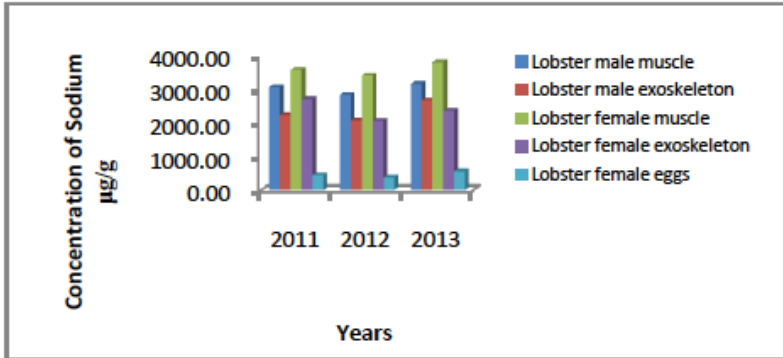

C

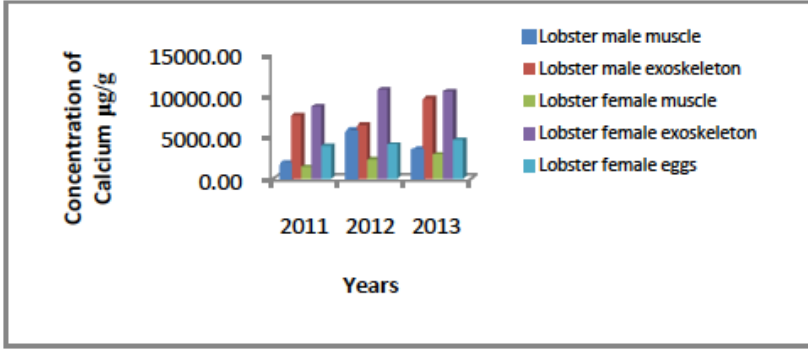

e

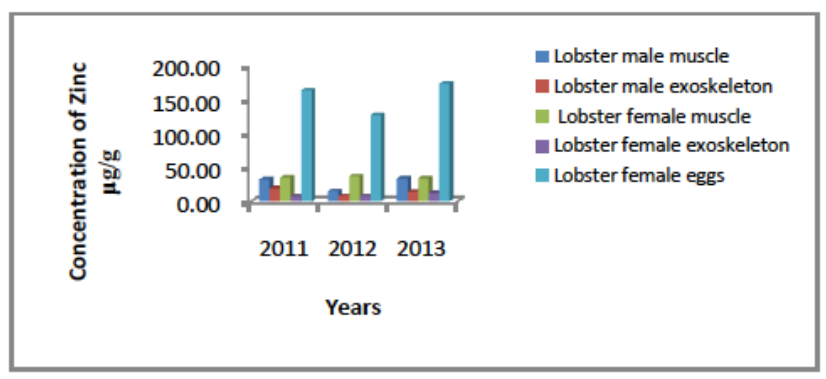

b

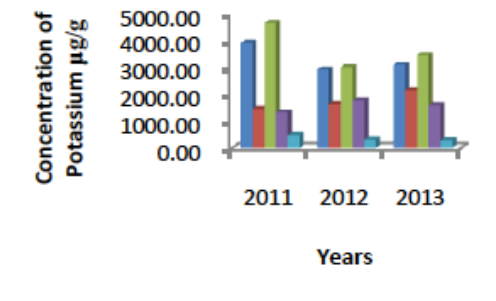

n Lobster male muscle

n Lobster male exoskeleton

- Lobster female muscle

n Lobster female exoskeleton

n Lobster female eggs

d

Figure 2: (a, b, c, d, e and f) Concentration of Copper, Zinc, Sodium, Potassium, Calcium and Magnesium respectively in different parts of male and female lobsters during the year 2011 to 2013 .

permissible range, i.e. $120 \mathrm{ppm}$ as recommended for the crustacean tissue [12]. While in case of lobster eggs, it was found to be higher than the recommended value of $\mathrm{Cu}$ in sea food, which is $30 \mathrm{ppm}$ [14]. The Food and Agricultural Organization [15] suggest limits for $\mathrm{Cu}$ is $30 \mathrm{mg} / \mathrm{kg}$ [16]. The Turkish legislation establishes maximum level for the $\mathrm{Cu}$ not permitted to $20.0 \mathrm{mg} / \mathrm{kg}$. Canadian Food Standard is $100 \mu \mathrm{g} / \mathrm{g}$, Hungarian standard 60 $\mathrm{\mu g} / \mathrm{g}$, Malaysian Food Regulation (1985) limits $120 \mu \mathrm{g} / \mathrm{g}$, while the range of international standard is in between $10-100 \mu \mathrm{g} / \mathrm{g}$ [1617].

The Zinc level in the muscle and exoskeleton of both male and female lobsters in three years study shown in Table $\mathbf{2}$ and Figure $\mathbf{2 b}$. Zn was found to be lower than the permissible level, i.e. $400 \mathrm{ppm}$ in crustacean tissue for human consumption [12]. However the values were much lower than the permissible limit for human consumption, which is 100 ppm for marine sea food $[12,18]$. The Food and
Agricultural Organization suggest limits for $\mathrm{Zn}$ is 30 $\mathrm{mg} / \mathrm{kg}$ for human consumption, the Turkish legislation establishes maximum levels for the $\mathrm{Zn}$ is not permitted above $50 \mathrm{mg} / \mathrm{kg}$, Canadian Food Standard is $100 \mu \mathrm{g} / \mathrm{g}$, by Hungarian Standard is $80 \mu \mathrm{g} / \mathrm{g}$, Australian Standard is $10 \mu \mathrm{g} / \mathrm{g}$ but these limits can be slightly higher in composite eggs $[15,16,19,20]$. Result showed that significant variations of $\mathrm{Zn}$ accumulation in different parts of male and female lobsters at $p<0.01$ or $p<0.05$. It is generally believed that crustacean actively regulate $\mathrm{Zn}$ concentrations in their body tissues and therefore $\mathrm{Zn}$ level do not reflects the changes in $\mathrm{Zn}$ concentrations in the marine environment $[12,21]$.

Lobsters are appreciated internationally as good diet for human and other organisms. It is nutritionally important source of protein, vitamins and dietary minerals like sodium, potassium, calcium, magnesium. Usually, calcium content is high in crustaceans and it is chiefly found in the skeleton as calcium carbonate. Therefore concentration of calcium ion is generally high 
in the body [22-23]. Minerals are grouped as macronutrients and their characterization depends upon the body requirements commonly known as major mineral. Results are summarized in Table 2 and Figure $\mathbf{2 c}, \mathbf{d}$, $\mathbf{e}$ and $\mathbf{f}$ which shows the accumulation level of minerals $(\mathrm{Na}, \mathrm{K}, \mathrm{Ca}, \mathrm{Mg})$ in muscles and exoskeleton of both male and female lobsters during the three years study. Previous results showed the concentration of $\mathrm{Na}, \mathrm{K}, \mathrm{Ca}$ and $\mathrm{Mg}$ in muscle of shrimps were 23030 , $31772,1680,670 \mathrm{mg} / \mathrm{kg}$ respectively [24-25] and $3018.98,4479.64,1016.12$ and $650.28 \mathrm{mg} / \mathrm{kg}$ in muscle of shrimp respectively [25-26]. Comparison to the present result, it is observed that $\mathrm{Ca}$ and $\mathrm{Mg}$ found relatively high concentration in lobster samples while $\mathrm{Na}$ and $\mathrm{K}$ found within the permissible level. Although there is very little information about the minerals accumulation level in crustaceans. Strong positive correlation were found in between the metals during the three years study at $p<0.01$ or $p<0.05$ among the different parts of male and female lobsters.

Present study reveals the importance of Pakistani lobsters as safe and quality sea food for export. The available evidence indicates us that the accumulation level in male and female lobsters are slight differ in their physiological requirements for these metals. Almost all metals and minerals measured in this study are relatively lower than their toxicity limits, recommended by FAO, FEPA and WHO. Therefore, these lobsters did not pose any threat to human health upon their consumption.

\section{ACKNOWLEDGEMENT}

The authors of this paper greatly acknowledged the Dean, Faculty of Science, University of Karachi, Pakistan for the support and fund provided to ease this research.

\section{REFERENCES}

[1] Sriket P, Benjakul S, Visessanguan W, Kijroongrojana K. Comparative studies on chemical composition and thermal properties of Black Tiger Shrimp (Penaeus monodon) and White Shrimp (Penaeus vannamei) meats. Food Chem 2007; 103: 1199-1207.

http://dx.doi.org/10.1016/i.foodchem.2006.10.039

[2] Heu MS, Kim JS, Shahidi F. Components and nutritional quality of shrimp processing by products. Food Chem 2003; 82: 235-242.

http://dx.doi.org/10.1016/S0308-8146(02)00519-8

[3] Balfour S, Badrie N, Yen IC, Chatergoon L. Seasonal influence and heavy metal analysis in marine shrimp (Penaeus spp.) sold in Trinidad, West Indies. J Food Res 1 2012; 193-199.

\section{http://dx.doi.org/10.5539/ifr.v1n1p193}

[4] Gokoglu N, Yerlikaya P, Gokoglu M. Mini - Review: Trace elements in edible tissues of three shrimp species (Penaeus semisulcatus, Parapenaeus longirostris and Paleo monserratus). J Sci Food Agric 2008; 8: 175-178.

\section{http://dx.doi.org/10.1002/jsfa.3086}

[5] Yilmaz AB, Yilmaz L. Influences of sex and seasons on level of heavy metals in tissues of Green Tiger Shrimp (Penaeus semisulcatus de hann, 1844). Food Chem 2007; 101: 16641669.

http://dx.doi.org/10.1016/j.foodchem.2006.04.025

[6] Barrento S, Marques A, Teixeira B, Anacleto P, Carvalho ML, Pires PV, Nunes ML. Macro and Trace elements in two populations of Brown Crab (Cancer pagures): Ecological and human health implications. J Food Composit Anal 2009; 22: 65-71.

http://dx.doi.org/10.1016/i.jfca.2008.07.010

[7] Wu XY, Yang YF. Heavy metal (Pb, Co, Cd, Cr, Cu, Fe, Mn and $\mathrm{Zn}$ ) concentrations in harvest size white shrimp Litopenaeus vannamei tissues from aquaculture and wild source. J Food Composit Anal 2011; 24: 62-65.

http://dx.doi.org/10.1016/i.jfca.2010.03.030

[8] Huda IA, Khan SA. Biodiversity of benthic fauna in KorangiPhitti creek system at different ecological niches. Proceedings of the UNESCO workshop on coastal aquaculture 1996; 37-46.

[9] Iqbal M, Kazmi MA. Coastal zone management in Pakistan with special reference to marine pollution impact and ICAM plan. Proceedings of the UNESCO workshop on coastal aquaculture 1996; 47-52.

[10] Turkmen G. Seasonal variations of heavy metals in Shrimp Penaeus kerathurus (forskal, 1775) from Izimr Bay. Turk J Anim Veter Adv 2012; 11(15): 2839-2844.

http://dx.doi.org/10.3923/javaa.2012.2839.2844

[11] Pournag N, Dennis JH. Distribution of trace metals in tissues of two shrimp species from the Persian Gulf and roles of metallotheonien in their redistribution. Environ Int 2005; 31: 325-341.

http://dx.doi.org/10.1016/i.envint.2004.08.003

[12] Mitra A, Barua P, Zaman S, Banerjee K. Analysis of trace metals in commercially important crustaceans collected from UNESCO protected world heritage site of Indian Sundarbans. Turk J Fisheries Aquatic Sci 2012; 12: 53-66. http://dx.doi.org/10.4194/1303-2712-v12 107

[13] Mumtaz M. Geochemical studies of heavy metals in the sea water along Karachi - Makran coast." Ph.D, Thesis, Department of Chemistry, University of Karachi, Karachi 2002.

[14] World Health Organization. Heavy metals environmental aspects. Environmental Health Criteria, Geneva, Switzerland 1989; 85.

[15] FAO, Compilation of legal limits for hazardous substances in fish and fishery products. Food and Agriculture Organization of the United Nations (1983) FAO Fishery Circular No. 464, 5-10. Rome

[16] Tabinda AB, Hussain M, Ahmed I, Yasar A. Accumulation of toxic and essential trace metals in fish and prawns from Keti Bunder Thatta District, Sindh. Pak J Zool 2010; 42(5): 631638.

[17] USEPA, Guidance for assessing chemical contaminant, Data for use in fish advisories. Fish sampling and Analysis, 1 $\left(3^{\text {rd }}\right.$ ed) Office of Water; Washington, DC (2000): EPA 823-R95-007.

[18] FAO, FAO/WHO, Food standard program, $2^{\text {nd }}$ ed. Codex Alimentarius Commission 1992; 1: 114-190.

[19] Papagiannis I, Kagalou I, Leonardos J, Petridis D, Kalfakakou V. Copper and zinc in four freshwater fish species from Lake Pamvotis (Greece). Environ Int 2004; 30 : 357-362.

http://dx.doi.org/10.1016/..envint.2003.08.002

[20] TFC, Turkish food codes. Official Gazette 2002; 24885. 
[21] Rejamon G, Nair M, Joseph T. Trace metal dynamics in fishes from the south west coast of India. Environmental Monitoring Assessment 2010; 167: 243-255. http://dx.doi.org/10.1007/s10661-009-1046-y

[22] Greenaway P. Calcium balance and moulting in the crustacea. Biol Rev 2008; 3: 425-454.

[23] Mohapatra A, Rautray TR, Patra AK, Vijayan V, Mohanty RK. Trace element-based food value evaluation in soft and hard shelled mud crabs. Food Chem Toxicol 2009; 47: 2730-2734. http://dx.doi.org/10.1016/j.fct.2009.07.037

[24] llesanmi AE, Adubiaro HO. Chemical composition of shell and flesh of three prawn samples from Lagos lagoon. J Sci Food Agric 2004; 84(5): 411-414. http://dx.doi.org/10.1002/jsfa.1649
[25] Javaheri BM, Velayatzadeh M, Branch A. Determination of Heavy Metals and Trace Elements in the Muscles of Marine Shrimp, Fenneropenaeus Merguiensis from Persian Gulf, Iran. J Anim Plant Sci 2013; 23(3): 786-791.

[26] Ozden O. Seasonal differences in the trace metal and macrominerals in shrimp (Parapenaus longirostris) from Marmara Sea. Environ Monit Assessment 2010; 162: 191199.

http://dx.doi.org/10.1007/s10661-009-0787-y

Received on 04-01-2015

Accepted on 29-04-2015

Published on 12-05-2015

DOI: http://dx.doi.org/10.6000/1927-5951.2015.05.02.2

(C) 2015 Kamal et al.; Licensee Lifescience Global.

This is an open access article licensed under the terms of the Creative Commons Attribution Non-Commercial License (http://creativecommons.org/licenses/by-nc/3.0/) which permits unrestricted, non-commercial use, distribution and reproduction in any medium, provided the work is properly cited. 